\title{
ENERGY CONSUMPTION IN THE US RECONSIDERED. EVIDENCE ACROSS SOURCES AND ECONOMIC SECTORS.
}

\section{Mónica Carmona, Julia Feria, Antonio A. Golpe, Jesus Iglesias}

\begin{abstract}
This study analyzes the impact of GDP shocks in USA on primary energy consumption and the reverse impact in a comprehensive and novel framework, distinguishing by economic sectors (commercial, industrial, residential and transportation) and energy source, i.e., total fossil (coal, natural gas and petroleum), nuclear, and renewable (hydroelectric, geothermal and biomass) for the period 1973:1 to 2015:2. To this end, we apply Granger causality analysis through the Hatemi-J [1] and Toda and Yamamoto [2] approaches from a time series perspective to evaluate the existence of asymmetries on this bidirectional relationship. The empirical results suggest that the impact of GDP on primary energy consumption is heterogeneous and energy source-specific, and an asymmetric behavior appears among cycles. Moreover, it seems clear that the US economy is highly dependent on petroleum energy consumption. The renewable energy sources do not seem to show any relationshipsources seem to show no relationship with economic growth, and finally, our results suggest that energy consumption in the industrial sector is key to economic growth and is also very sensitive to negative economic shocks.
\end{abstract}

Keywords: Energy consumption; growth; Granger causality, asymmetric causality.

\section{Introduction}

Meeting the essential energy needs economically and sustainably requires a balanced energy portfolio that is suited to the economic, social, and resource conditions of individual countries and regions [3]. Furthermore, the International Energy Agency [4] warns that current trends in energy supply and use are still economically, environmentally and socially unsustainable. In this context, renewable energy sources, such as wind, solar, hydro, geothermal, and bioenergy, have partially replaced the fossil fuels and nuclear power in four distinct markets: power generation, thermal applications, transport fuels energy and non-networked services in rural areas in developing countries. Overall, investment in renewable energy has grown exponentially 
in recent years - from 22,000 million dollars in 2004 to 211,000 million dollars in 2010 - while the involvement of countries in promoting the use of alternative energy sources has also been evident; 118 countries had some types of policies to support renewable energy, well above the 55 countries that had such policies in place in 2005 [5]. In 2012, the USA was responsible for $18 \%$ of the world's total primary energy consumption. In this country, petroleum is the main source of energy among the fossil fuels in the U.S. energy mix. Nevertheless, renewable energies have experienced a remarkable popularity in recent years, when the use of renewable energy increased from approximately 16.8 million metric tons of oil equivalent in 2001 to nearly 60 million metric tons of oil equivalent in 2013, whereas 13 percent of the nation's total electricity generation was derived from biomass, hydro and wind sources.

Comprehending the actual direction of causality between energy consumption and economic growth has substantial implications for policymakers as well as for the natural environment, at least with respect to reducing the consumption of non-renewable energies and consequently the impact on the environment through the reduction of carbon dioxide $\left(\mathrm{CO}_{2}\right)$ emissions [6]. A unidirectional causal relationship from energy consumption to growth reflects an unsustainable energy security situation even with high energy resources present in one country [7]. From an optimistic point of view, continuous technological advancements and the possibility of substitution of natural inputs with manmade capital sustains growth trends ([8] or [9]). However, in terms of empirical research, academics are far from establishing a clear consensus about the direction of causality.

Although many studies have investigated the relation between energy consumption and economic growth, few studies have paid attention to this relationship by breaking down the different energy sources and distinguishing by economic sectors. To shed more light on this relationship, in this paper, we analyze the impact of GDP shocks in the USA on primary energy consumption (and viceversa) applying a Granger causality approach. As a novel approach in terms of the previous literature, we investigate the possible existence of asymmetries on the bidirectional relationship, distinguishing by total fossil (coal, natural gas and petroleum), nuclear and renewable (hydroelectric, geothermal and biomass) energies and by economic sector, in a comprehensive study on the little-studied possible relationship between growth and energy consumption. In 
other words, our paper presents a novel study in the energy economics literature that not only explores the causal relationships by sector, but even more importantly, it also investigates how to vary these relationships for different economic cycles. To accomplish this, we analyze a sample of these energy sources for the USA during the period 1973:Q1 to 2015:Q2, using real GDP as the economic growth indicator. Our econometric strategy consists of a set of techniques developed by Hatemi-J [1] and Toda and Yamamoto [2] for a Granger causality analysis from a time series perspective. Our results support heterogeneous evidence on the impact of GDP on primary energy consumption and the appearance of an asymmetric behavior among cycles.

The remainder of this paper is organized according to the following scheme. Section 2 illustrates the theoretical and empirical background on energy consumption and growth. Section 3 provides the data and methods description used in the empirical analysis. Section 4 outlines the main results, and section 5 provides the main conclusions and some useful recommendations for policy makers.

\section{The relationships between energy and GDP growth}

Since the seminal work of Kraft and Kraft [10], in which the relationship between energy consumption and GDP growth was established for the USA with causality running from GDP to energy, much literature concerning this relationship has sought to determine the direction of causality. Nonetheless, a common alternative is to study this relationship from the supply side in a production function approach [see for instance [11] or [12]), and from a demand side perspective that investigates the relationship between energy consumption, economic growth and energy prices [see [13] or [14] among others]. However, as is well known, this emerging literature can be divided into three strands depending on the focus of research: 1) environmental pollutants and GDP growth, which tests the validity of the Environmental Kuznet's Curve (EKC) hypothesis; 2) the causality running from GDP to energy; and 3) a combined approach, which is perhaps the least studied [7].

Thus, many researchers have emerged who have put the focus on the supply or demand side, including a range of control variables, in order to establish a complete explanation of the relationship between GDP and energy consumption. The possibilities 
that can drive the production model will depend on the availability; for example, the different economies may have different sources in relation to costs and prices. For instance, renewable energy sources remain significantly more expensive than fossil fuel and represent only a small fraction (less than 5\%) of the total primary US energy consumption. This small contribution may explain why there is no causality between renewable energy sources and economic growth. Camarero et al., [15] show a broad overview of the control variables used in the literature with the aim of measuring the relationship between energy consumption and economic growth. These variables include: employment, energy prices, government spending, gross fixed capital formation, real money supply, energy intensity, energy efficiency, business sector productivity and exports.

Furthermore, a common problem in a bivariate analysis is the possibility of omitted variable bias ([16] or [17]). Recognizing this omitted variable problem, several studies incorporate additional variables in their analysis. However, the inclusion of control variables is not without problems. First, the choice of these variables has been ad hoc, made according to the subjective economic rationale of the authors [15]. Additionally, a recent survey by Narayan and Smyth [18] about this literature warns of the trade-off that necessarily emerges using the bivariate model, which is susceptible to omitted variable bias, and using a multivariate approach has an associated risk of overparameterization of the model, which contributes to estimation error [18]. Finally, the data about control variables are not as complete as those about the energy consumption and GDP variables, either in terms of high frequency data or time span. To avoid this problem, in our study, we propose a bivariate analysis to test the energy consumptionGDP nexus causality by sector and address asymmetries.

To establish a comprehensive framework on the energy consumption and growth relationship, following the main surveys in the literature, including the works of Kraft and Kraft [10], Özturk [19] and recently Omri [20], several hypotheses have been developed on this regard, summarizing the causal relationship in four ways. First, the Growth hypothesis suggests that energy consumption causes GDP growth; i.e., the availability of abundant cheap energy sources promotes economic growth. In that sense, although increases in energy consumption may contribute to further economic growth, reductions in energy consumption may have negative effects on growth. Second, the Conservation hypothesis recognizes the unidirectional causality from GDP growth to 
energy consumption and consequently any conservation policies concerning energy consumption will have little or no adverse effect on economic growth. Third, the Feedback hypothesis suggest bidirectional causality flows between GDP and energy consumption. Finally, the Neutrality hypothesis or no causality suggests no correlation between GDP and energy consumption and consequently energy scarcity and conservative policies in relation to energy use do not affect economic growth.

A great part of the existing research has been conducted on developed countries due the fact that high frequency data and time span are complete only in these countries. He shows in a review of 48 articles that regarding the energy consumption-growth connection, $29 \%$ of the articles support the growth hypothesis, $27 \%$ of the articles support the feedback hypothesis, $23 \%$ of the articles support the conservation hypothesis, and $21 \%$ of the articles support the neutrality hypothesis. Previously, Payne [17] provided similar results in his survey, concluding in an analysis including 101 studies over the period 1978 to 2008 that there was no clear consensus: $23.1 \%$ of the studies showed unidirectional causality from energy consumption to GDP growth, $19.5 \%$ of the studies found causality from GDP growth to energy consumption, $28.2 \%$ of the studies showed a bidirectional relationship, and $29.2 \%$ of the studies showed no relationship.

Although all of these hypotheses may be equally valid, it is only possible to discriminate between them empirically; unfortunately, the empirical findings do not provide conclusive results. There are various reasons for the lack of consensus in the literature. A great part of the existing research has been conducted for developed countries, due the fact that data, frequency and time span are complete only in these countries. Among the factors involved in this controversy over the link between growth and energy consumption, we can find in the literature some potential sources, such as the sample periods, model specifications, different consumption patterns, omitted variable bias, trade agreements among countries, structural frameworks and the policies followed by countries, the varying impacts from different sources of energy, their energy imports and exports profile, the different development stages and processes in each country or the cross-section dependence between countries, which is usually overseen and leads to biased results (see [17], [19], [20] or [21], for a surveys). ${ }^{1}$ In that

\footnotetext{
${ }^{1} \mathrm{Kraft}$ and Kraft [10] summarizes four primary econometric approaches to analyze the causal relationship: GrangerSims causality testing, Engle-Granger/Johanssen-Juselius cointegration and error-correction modeling, Toda-
} 
sense, Menegaki [7] argues that the long-run elasticity of GDP growth with respect to energy consumption is not independent of the method employed for cointegration, the data type and the inclusion of variables, such as the price level or capital, in the cointegration equation. Hence, he proposes that a $1 \%$ increase in capital increases the elasticity of GDP with respect to energy consumption by $0.85 \%$. However, the recent meta-analysis by Kalimeris et al. [21] supports neither the existence of a fundamental "macro" direction nor the so-called neutrality hypothesis in the causal relationship between energy consumption and economic growth.

Nonetheless, another factor that arises in the mentioned empirical controversy is the type of energy included in the analysis that addresses the causality between energy consumption and growth. Although most studies have used electricity as a source of energy consumption, in recent years there has been a growing interest in knowing the relationship between the different sources of energy and economic growth, i.e., the fossil fuels, nuclear energy and renewable energy. According to the recent survey by Omri [20], we can observe empirical evidence supporting each type of hypothesis with several energy sources. Concerning the electricity consumption-growth connection, $40 \%$ of the studies in the survey supported the growth hypothesis, $33 \%$ of the studies supported the feedback hypothesis, and $27 \%$ of the studies supported the conservation hypothesis; regarding the nuclear consumption-growth nexus: $60 \%$ of the studies supported the neutrality hypothesis, and $40 \%$ of the studies supported the growth hypothesis; and concerning the renewable consumption-growth nexus: $40 \%$ of the studies supported the neutrality hypothesis, $40 \%$ of the studies the conservation hypothesis and $20 \%$ of the studies supported the growth hypothesis. Ohler and Fetters [22] contribute with empirical research concerning different energy sources across 20 OECD countries from 1990 to 2008, showing four sets of results from a commonly used panel error correction model. A bidirectional relationship between aggregate renewable generation and real GDP exists, whereas biomass, hydroelectricity, waste, and wind energy exhibit a positive long-run relationship with GDP. Conversely, hydroelectricity and waste generation exhibit a short-run positive bidirectional relationship with GDP

Yamamoto long-run causality testing, and panel cointegration error correction modeling. Belke et al. [23] summarize the main econometric approaches used in the literatura: the vector autoregression method (VAR), which assumes stationarity of the underlying variables; the Engle and Granger procedure, which also considers non-stationarity; Johansen's multivariate approach, which includes more variables in the cointegration relationship; and the panel estimation techniques. 
growth, and finally biomass, hydroelectric, and waste electricity generation have the largest impact on real GDP in the long-run. Ohlen and Fetters also analyze the existence of structural breaks and cross-sectional dependence and find that in the short-run, increases in biomass and waste generation negatively affect GDP, whereas aggregate renewable and hydroelectricity increase GDP. Ohler and Fetters [22] also argue that biomass and waste generation are important drivers in the renewable energy-GDP relationship, but the environmental impacts between sources vary. ${ }^{2}$

Finally, to conduct a complete analysis concerning the causality between growth and energy consumption, we wonder if this relationship holds in different economic sectors. Gross [24] warn that bivariate models, which analyze the causality only at the macro level, are eventually misleading because the relationship between energy and growth seems to be neutral on the macro level; however, the Granger causality for a lower level of aggregation in some cases emerges (see [25]; [26]). In other words, he reminds us of 'Simpson's Paradox' [27], who argued that in statistical analyses it is not uncommon that evidence can be found for a lower level of aggregation while the results for the total population suggest the opposite. ${ }^{3}$ Another reason is that the literature recognizes that the different energy demands that exist for each economic sector are supported by the EKC hypothesis. The shift in the composition of output in the economy could affect the energy consumption-output relationship because different industries may have different energy intensities, i.e., when the country passes to an economy based on the service sector, the energy demands decline [28]. Thus, to find an adequate response to this, it is necessary to include matters related to the capture of the GDP allocation by the three productive sectors because some of the divergence across sectors can be explained by the fundamental differences between goods and service producing industries [24].

The next subsection is devoted to an explanation of the relationship established

\footnotetext{
2 Omri et al. [29] provides an extensive summary of empirical studies on the causality between nuclear and renewable energy consumption and growth (see Table 1).

${ }^{3}$ Gross [24] warns that the potential linkages between the input of transport fuels and the related output would be distorted by all other economic activities. As an example, he proposes that total GDP is dominated by the commercial sector, which does not make extensive use of transport services compared to the industry sector. Taking GDP as the growth variable would then mainly account for production processes in which transport services are not required.
} 
between growth and each specific source of energy, total fossil (coal, natural and petroleum), nuclear and renewable energies (hydroelectric, geothermal and bio-mass) and by economic sector (commercial, industrial, residential and transportation). To explore the mentioned puzzle regarding the causal relationship and the direction, we provide in Table 1 a summary of selected papers following the exhaustive survey of Omri [20], classified by author, country, period, energy source and its measure, data source, methodology, the main result and the confirmed hypothesis. In this survey, we observe that these mixed results are also supported in the recent literature.

\section{Existing empirical evidence in the US}

The novel study analyzing the causal relationship among energy consumption and growth in the USA was conducted by Kraft and Kraft [10], who found that GDP caused energy consumption. Later Stern [30] found support for thisor this result and revealed that the opposite causality also appeared. At the moment, the evidence is still mixed in the US. The causes of this lack of consensus can be found in the arguments above. Nevertheless, the majority of studies at a macro perspective for the U.S. find neutrality between energy and growth at the macro level [24]. However, among the results that emerge in literature, common analysis of the causal link between growth and energy consumption has not discriminated between power sources. Attention in recent years has perhaps mainly focused on the distinction between renewable and nonrenewable energies. In fact, Sari et al. [31] analyzed the two-way causality between renewable energy consumption and industrial energy consumption in the USA over the period of 1969-2009 and found support for the conservation hypothesis.

To obtain a better understanding of the use of energy sources and their role in growth, the empirical evidence available in the case of the US has produced some interesting results. Kum et al. [32] found evidence of bidirectional Granger-causality between natural gas and growth. Payne [33] found evidence of unidirectional Grangercausality running from biomass energy consumption to real GDP and hence obtained support for the growth hypothesis. In another work, Payne [34] analyzed the case of coal consumption neglect the Granger-causality between coal consumption and real GDP; however, he found support for positive unidirectional Granger-causality running from real GDP to natural gas consumption and positive unidirectional Granger-causality running from petroleum consumption to real GDP. 
Regarding the USA renewable energies evidence, the Conservation Hypothesis has been supported by Sari et al. [30] and Menyah and Wolde-Rufael [35], who found support for unidirectional causality from growth to renewable energy. Other contributions have appeared in favor of the Growth Hypothesis: for instance, [33] and [28]. Finally, there is also evidence in line of the Neutrality Hypothesis in the case of renewable energies in the work of Payne [36]. Particularly, biomass energy has been investigated in Payne [33] through the causal relationship between biomass energy consumption and real GDP, where the empirical findings revealed the growth hypothesis.

Another line of research has investigated the relationship of growth and energy consumption focusing on the economic sectors, and some interesting results emerge in the existing literature for the U.S. For instance, Bowden and Payne [25] found evidence that the relationship between energy consumption and real GDP is not uniform across sectors. Bowden and Payen also affirm that Granger-causality is absent between total and transportation primary energy consumption and real GDP, while bidirectional Granger-causality is present between commercial and residential primary energy consumption and real GDP, respectively. Finally, their results indicate that industrial primary energy consumption Granger-causes real GDP. In another study, Gross [24] finds evidence for unidirectional long-run Granger causality in the commercial sector from growth to energy. He also finds evidence for bidirectional Granger causality in the transport sector, whereas in the industrial sector, controlling for trade is important for identifying short-run Granger causality when growth is the dependent variable. 


\section{Table 1}

Selected papers on the energy consumption and growth hypothesis after 2014

\begin{tabular}{|c|c|c|c|c|c|c|}
\hline Study & Country or countries & Period & Energy source and measure* & Data source & Methodology & Main result: Confirmed hypothesis \\
\hline$[37]$ & 80 countries & $1990-2012$ & $\begin{array}{l}\text { Renewable energy, real gross fixed capital } \\
\text { and labor }(\mathrm{L}) \text {. }\end{array}$ & $\begin{array}{l}\text { U.S. Energy Information } \\
\text { Administration and World } \\
\text { Bank Development Indicators } \\
\text { (WDI) }\end{array}$ & $\begin{array}{l}\text { Canning and Pedroni long- } \\
\text { run causality test }\end{array}$ & $\leftrightarrows$ Feedback Hypothesis \\
\hline$[6]$ & U.S. & 1973q1-2012q1 & Primary energy consumption & $\begin{array}{l}\text { U.S. Energy Information } \\
\text { Administration and the } \\
\text { Bureau of Economic Analysis } \\
\text { of the U.S. Department of } \\
\text { Commerce }\end{array}$ & Granger causality tests & $E C \mapsto G D P-$ Growth Hypothesis. \\
\hline$[35]$ & $\begin{array}{c}15 \text { developing countries: } \\
\text { Belarus, Bulgaria, Czech } \\
\text { Republic, Latvia, Lithuania, } \\
\text { Russian Federation;, Ukraine } \\
\text { Albania, Macedonia, } \\
\text { Moldova, Poland, Romania, } \\
\text { Serbia, Slovak Republic and } \\
\text { Slovenia. }\end{array}$ & 1975-2010 & Electricity consumption per capita & WDI (2013) & Panel causality approach & $\begin{array}{l}E C \mapsto G D P-\text { Growth Hypothesis. (Belarus and Bulgaria); } E C \leftrightarrow \text { Growth - } \\
\text { Conservationh hypothesis (Czech Republic, Latvia, Lithuania and the Russian } \\
\text { Federation); } \leftrightarrows \text { Feedback Hypothesis. (Ukraine -no Granger causality Albania, } \\
\quad \text { Macedonia, Moldova, Poland, Romania, Serbia, Slovak Republic and Slovenia). }\end{array}$ \\
\hline$[38]$ & $\begin{array}{l}\text { Bangladesh, Bangladesh } \\
\text { Egypt, Indonesia, Iran, } \\
\text { Korea } \\
\text { Mexico, Pakistan, } \\
\text { Philippines, Turkey (N-11 } \\
\text { countries except for Nigeria } \\
\text { and Vietnam) }\end{array}$ & 1971-2007/10/11 & Energy use per capita & WDI (2013) & $\begin{array}{l}\text { [2] bootstrapped AR metric } \\
\text { causality approach }\end{array}$ & $\begin{array}{c}\leftrightarrow \text { Neutrality hypothesis (all of the countries except for Turkey). EC } \mapsto G D P- \\
\text { Growth Hypothesis (Turkey) }\end{array}$ \\
\hline [22] & $\begin{array}{c}20 \text { OECD countries: } \\
\text { Australia, Austria, Belgium, } \\
\text { Canada, Denmark, France, } \\
\text { Germany, Iceland, Italy, } \\
\text { Japan, Luxembourg, } \\
\text { Netherlands, New Zealand, } \\
\text { Norway, Portugal, Spain, } \\
\text { Sweden, Switzerland, United }\end{array}$ & 1990-2008 & $\begin{array}{l}\text { Gross electricity production. Coal (bit.) } \\
\text { Coal, Biomass. }\end{array}$ & $\begin{array}{l}\text { International Energy Agency's } \\
\text { dataset on world renewable } \\
\text { and waste energy statistics \& } \\
\text { OECD. }\end{array}$ & $\begin{array}{l}\text { Several panel cointegration } \\
\text { tests, panel error correction } \\
\text { models and analysis for } \\
\text { structural breaks and cross- } \\
\text { sectional dependence }\end{array}$ & $\leftrightarrows$ Feedback Hypothesis \\
\hline
\end{tabular}




\begin{tabular}{|c|c|c|c|c|c|c|}
\hline Study & Country or countries & Period & Energy source and measure* & Data source & Methodology & Main result: Confirmed hypothesis \\
\hline & Kingdom, and United States. & & & & & \\
\hline$[39]$ & $\begin{array}{l}\text { Brazil, Russian, India, China, } \\
\text { Turkey and South Africa }\end{array}$ & 1980-2011 & $\begin{array}{l}\text { OEC (oil energy consumption), CEC (coal } \\
\text { energy consumption), NGC (natural gas } \\
\text { energy consumption) }\end{array}$ & $\begin{array}{l}\text { BP Statistical Review of } \\
\text { World Energy 2011, WDI } \\
\text { and International Financial } \\
\text { Statistics of the IMF } \\
\text { (International Monetary } \\
\text { Fund). }\end{array}$ & $\begin{array}{l}\text { ARDL (autoregressive } \\
\text { distributed lag bounds) }\end{array}$ & $\begin{array}{l}\leftrightarrows \text { Feedback hypothesis: Bi-directional causality OEC and Y for all countries (long-run } \\
\text { causality for China and India). NGC and Y for Brazil, Russia and Turkey. }\end{array}$ \\
\hline [40] & U.S. & $\begin{array}{l}\text { January } 1973- \\
\text { October } 2011 .\end{array}$ & $\begin{array}{l}\text { Natural Gas Consumption, Primary Energy } \\
\text { Consumption Total, Coal Consumption, } \\
\text { Total Electricity End Use, Total Renewable } \\
\text { Energy Consumption and real GDP. }\end{array}$ & $\begin{array}{l}\text { U.S. Energy Information } \\
\text { Admin- istration (June 2012 } \\
\text { Monthly Energy Review) and } \\
\text { http://www.bea.doc.gov/.3 }\end{array}$ & $\begin{array}{l}\text { Asymmetric Granger- } \\
\text { causality developed by } \\
\text { Hatemi-J }\end{array}$ & $\begin{array}{l}\text { Asymmetric Granger-causality (i.e., Coal Consumption (CC), Natural Gas Consumption (NG), } \\
\text { Primary Energy Consumption (PE), and Total Renewable Energy Consumption (TRE)) and GDP } \\
\text { (all measured in growth rates). Positive shocks - EC } \mapsto \text { GDP - } \\
\text { Growth Hypothesis. EC } \leftrightarrow \text { Growth - Conservationh hypothesis (growth } \\
\text { rate of Total Electricity End Use (EC) to GDP growth rate). } \leftrightarrows \text { Feedback H ypothesis (NG } \\
\text { and GDP, PE and GDP and TRE and GDP). Negative shocks - growth rates in CC and TRE do } \\
\text { not Granger-cause GDP growth. }\end{array}$ \\
\hline [41] & China, Brazil and India & 1971-2010 & $\begin{array}{l}\text { Renewable energy; } \mathrm{CO} 2 \text { while trade } \\
\text { openness. }\end{array}$ & WDI & $\begin{array}{l}\text { The ARDL bounds testing } \\
\text { approach to cointegration and } \\
\text { vector error correction model } \\
\text { (VECM) }\end{array}$ & $\leftrightarrows$ Feedback Hypothesis. (BRICS countries) \\
\hline$[42]$ & $\begin{array}{l}25 \text { EU countries: Austria, } \\
\text { Belgium, Bulgaria, Cyprus, } \\
\text { the Czech Republic, } \\
\text { Denmark, Estonia, Finland, } \\
\text { France, Hungary, Greece, } \\
\text { Germany, Ireland, Italy, } \\
\text { Latvia, Lithuania, the } \\
\text { Netherlands, Poland, } \\
\text { Portugal, Romania, Slovakia, } \\
\text { Slovenia, Spain, Sweden, } \\
\text { and the United Kingdom }\end{array}$ & 1993-2011 & $\begin{array}{l}\text { Energy consumption. Real gross fixed } \\
\text { capital formation per capita in constant } 2005 \\
\text { U.S. dollars. }\end{array}$ & WDI, 2013 & $\begin{array}{l}\text { Bootstrap Granger panel } \\
\text { causality approach proposed } \\
\text { by Kònya (2006) }\end{array}$ & $\leftrightarrow$ Neutrality \\
\hline
\end{tabular}




\begin{tabular}{|c|c|c|c|c|c|c|}
\hline Study & Country or countries & Period & Energy source and measure* & Data source & Methodology & Main result: Confirmed hypothesis \\
\hline$[43]$ & EU 15 & 1990-2011 & $\begin{array}{l}\text { Non-renewable energy consumption -total } \\
\text { petroleum products, natural gas and solid } \\
\text { fuels-. Renewable energy -biomass, } \\
\text { hydropower, geothermal energy, wind and } \\
\text { solar energy-. }\end{array}$ & EUROSTAT and OECD & $\begin{array}{c}\text { Pedroni Panel Cointegration } \\
\text { test, the fully modified OLS } \\
\text { (FMOLS) technique, panel } \\
\text { vector error correction model } \\
\text { (Pesaran et al., 1999) and } \\
\text { VECM Granger Causality } \\
\text { Test. }\end{array}$ & $\begin{array}{c}E C \mapsto G D P-\text { Growth Hypothesis. (Renewable }+ \text { Non renewable-) } \\
E C \leftrightarrow \text { Growth - Conservationh hypothesis. (Non renewable) }\end{array}$ \\
\hline [44] & $\begin{array}{l}51 \text { Sub-Sahara African } \\
\text { countries }\end{array}$ & 1980-2009 & $\begin{array}{l}\text { Biomass consumption [used extraction of } \\
\text { Biomass in kt]. }\end{array}$ & $\begin{array}{l}\text { Penn World Table, version } \\
8.0 \text { and Global Material Flow } \\
\text { Database }\end{array}$ & $\begin{array}{c}\text { Autoregressive (AR) and } \\
\text { individual AR processes, } \\
\text { considers panel common AR } \\
\text { and individual AR } \\
\text { cointegration analyses and } \\
\text { employs panel Dynamic } \\
\text { Ordinary Least Squares } \\
\text { (DOLS) }\end{array}$ & $E C \mapsto G D P-$ Growth Hypothesis \\
\hline$[45]$ & $\begin{array}{l}\text { G7 countries: Canada, } \\
\text { France, Germany, Italy, } \\
\text { Japan, the UK and the USA }\end{array}$ & 1980-2010 & $\begin{array}{l}\text { (iv) biomass consumption [used extraction } \\
\text { of Biomass]. }\end{array}$ & $\begin{array}{l}\text { Penn World Table and from } \\
\text { Global Material Flow } \\
\text { Database }\end{array}$ & $\begin{array}{l}\text { Uçnit root analyses, panel } \\
\text { cointegration analyses, } \\
\text { conventional OLS and } \\
\text { dynamic OLS analyses }\end{array}$ & $E C \mapsto G D P-$ Growth Hypothesis. E \\
\hline [46] & China & $\begin{array}{l}1977 \text { to } \\
\text { 2013(supply-side) } \\
\text { and } 1965 \text { to } 2011 \\
\text { (demand-side) }\end{array}$ & $\begin{array}{l}\text { Supply-side analysis - output, labor, capital, } \\
\text { coal consumption, oil consumption, } \\
\text { renewable energy consumption and } \\
\text { combined energy consumption. Demand- } \\
\text { side analysis - } \text {-income, coal consumption, oil } \\
\text { consumption, renewable energy, combined } \\
\text { energy consumption, coal price, crude oil } \\
\text { price, combined coal and oil price index and } \\
\text { carbon emissions. }\end{array}$ & $\begin{array}{l}\text { WDI of July 2013, } \\
\text { LABORSTA Labor Statistics } \\
\text { Database, Labor Organization } \\
\text { (ILO) and Statistical Review } \\
\text { of World Energy, } 2014 \\
\text { published by British } \\
\text { Petroleum (BP) }\end{array}$ & $\begin{array}{l}\text { Autoregressive distributed } \\
\operatorname{lag}(\mathrm{ARDL}) \text { and vector error } \\
\text { correction modeling (VECM) }\end{array}$ & $\begin{array}{c}E C \leftrightarrow \text { Growth }- \text { Conservationh hypothesis } \\
E C \mapsto G D P-\text { Growth Hypothesis. (coal, oil and renewables consumption, ) }\end{array}$ \\
\hline
\end{tabular}




\begin{tabular}{|c|c|c|c|c|c|c|}
\hline Study & Country or countries & Period & Energy source and measure* & Data source & Methodology & Main result: Confirmed hypothesis \\
\hline$[29]$ & $\begin{array}{l}\text { Argentina, Belgium, Brazil, } \\
\text { Bulgaria, Canada, Finland, } \\
\text { France, Hungary, India, } \\
\text { Japan, Netherlands, Pakistan, } \\
\text { Spain, Swe- den, } \\
\text { Switzerland, the United } \\
\text { Kingdom, and the United } \\
\quad \text { States. }\end{array}$ & 1990-2011 & $\begin{array}{l}\text { Nuclear energy consumption, renewable } \\
\text { energy consumption, gross fixed } \\
\text { capital,formation, total labor force, } \mathrm{CO} 2 \\
\text { emissions, real oil Price, crude oil, and oil } \\
\text { consumption. }\end{array}$ & $\begin{array}{l}\text { British Petroleum Statistical } \\
\text { Review of World Energy and } \\
\text { the WDI }\end{array}$ & $\begin{array}{c}\text { Two- stage least squares } \\
\text { (2SLS), three stage least } \\
\text { squares (3SLS), and the } \\
\text { generalized method of } \\
\text { moments (GMM) }\end{array}$ & 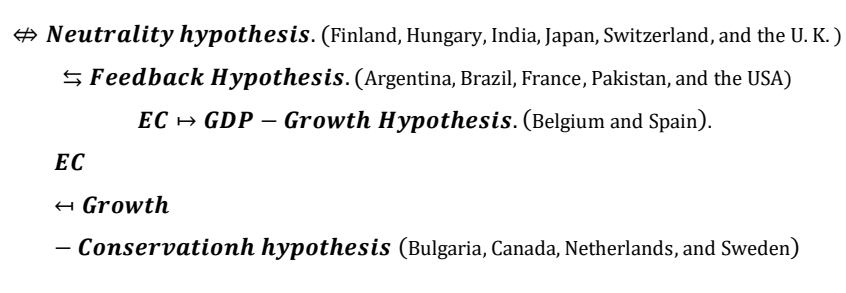 \\
\hline$[47]$ & Nigeria & 1971-2011 & Electricity power consumption per capita. & WDI, 2014 & $\begin{array}{l}\text { Phillips-Perron (PP) test, } \\
\text { and the Dickey-Fuller } \\
\text { generalised least squares } \\
\text { (DF-GLS) test KSS test, and } \\
\text { the Zivot-Andrews test. }\end{array}$ & $E C \mapsto G D P-$ Growth Hypothesis \\
\hline
\end{tabular}

* In all the papers summarized the real GDP is used as the measures of growth. $↔$ Neutrality hypothesis. $\leftrightarrows$ Feedback Hypothesis. EC $\mapsto$ GDP - Growth Hypothesis. EC $\leftrightarrow$ Growth -

Conservation hypothesis 


\section{Data and Methodology}

\subsection{Data}

In this paper, we analyze the nature of the relationship between the GDP and primary energy consumption by source and economic sector for the USA. The data used are quarterly observations from $1973: 1$ to $2015: 2$. The primary energy consumption, measured in quadrillion British Thermal Units $(\mathrm{BTu})$, is disaggregated by source, total fossil fuels (coal, natural gas, petroleum), nuclear energy, and total renewable energies (hydroelectric, geothermal, and biomass), and the total is extracted from the US Energy Information Administration (EIA). We approach our econometric applications by economic sectors: commercial, industrial, residential and transportation. The GDP data are taken from the US Bureau of Economic Analysis (BEA) and measured in billions of chained 2009 dollars. Before conducting the empirical analysis, the data were seasonally adjusted and converted to natural logarithms. The time plots of the series are shown in Appendix 1.

\subsection{Methodology}

The aim of our empirical strategy is to determine the possible existence of Granger causality relationships between GDP and energy consumption, using a set of econometric techniques to obtain more robust and comparable results. We analyze the Granger causality tests by applying the method proposed by Toda and Yamamoto [2] and, secondly, the methodology proposed by Hatemi-J [1] as an extension of Toda and Yamamoto [2], which allows us to analyze the asymmetric causality energy consumption by source and does not require us to previously test the existence of unit root or cointegration; that is, the variables in the system do not need to be stationary and can be used in level form.

\subsubsection{Granger causality: Toda-Yamamoto test.}

In energy economics, and more specifically in energy topics, perhaps the most common technique of examining the causality effects between variables is to use the Granger causality method based on the estimation of VAR models. The methodology proposed by Toda and Yamamoto [2] tries to measure causality to solve the problems stemming from the cointegration relationship and non-stationarity of the data series. 
Furthermore, an asymmetric structure in the study of causality suggested by Granger and Yoon [48] is considered and extended by Hatemi-J [1] to analyze the effects on causality relationships.

For a broad study of our proposed relationship, we propose the Toda-Yamamoto causality approach as a developed version of the Granger causality test based on augmented-VAR models in levels and extra lags, which is a more efficient and robust results than the standard VAR model because it can lead to biased results, particularly with finite samples; see [49], [50], [51], [52] and [53]. The main advantage of the TodaYamamoto test is that it can be applied irrespective of the order of integration or whether the time series are cointegrated [54]. In our exercise, a bivariate model including the GDP and energy consumption by the source variables under analysis, we can describe the benchmark model for this test as follows:

$$
\begin{aligned}
& G D P_{t}=\alpha_{1}+\sum_{i=1}^{p+d_{\max }} \beta_{1 i} G D P_{t-i}+\sum_{j=1}^{p+d_{\max }} \gamma_{1 j} \text { Energy }_{t-j}+\varepsilon_{1 t} \\
& \text { Energy }_{t}=\alpha_{2}+\sum_{i=1}^{p+d_{\max }} \beta_{2 i} \text { Energy }_{t-i}+\sum_{j=1}^{p+d_{\max }} \gamma_{2 j} G D P_{t-j}+\varepsilon_{2 t}
\end{aligned}
$$

According to the Akaike Information Criterion (AIC), $\mathrm{p}$ is the optimal lag length structure for the VAR model, where $d_{\max }$ is an extra lagged explanatory variable, i.e., is the maximum order of integration for the variables considered in the model, and $\varepsilon_{1 t}$ and $\varepsilon_{2 t}$ are residual terms that are Gaussian distributed and follow white noise processes. Hence, this test estimates a $\operatorname{VAR}(k)$ model using a Modified Wald test (MWALD) whose statistic is asymptotically distributed as chi-squared with p degrees of freedom. Therefore, we only need to establish the maximum order of integration $d_{\max }$, and construct a VAR in their levels with a total of $\mathrm{p}+d_{\max }$ lags."

To test the Granger causality between these two variables, note, for the first equation, that $\sum_{j=1}^{p} \gamma_{1 j} \neq 0$ implies that Energy $y_{t}$ Granger causes $G D P_{t}$. Analogously, in the second equation, $\sum_{j=1}^{p} \gamma_{2 j} \neq 0$ implies that GDP Granger causes Energy $y_{t}$ 
Consequently, rejecting both hypotheses implies that there exists bidirectional causality in the analyzed relationship.

\subsubsection{Looking for asymmetric causality relationships.}

Concerning the empirical works, in many cases, causality is rejected because no nonlinear relationships are contemplated. To address this issue, a nonlinear test developed by Hatemi-J [1] based on the initial ideas of Granger and Yoon [41] is applied in our exercise, allowing us to determine whether the cumulative positive and negative shocks can cause different impacts on the causal relationship between GDP and energy consumption by source. In other words, This test allows for asymmetry in causality and separates the potential causal impact of positive (negative) shocks from the positive (negative) ones. Following this strategy, we initially specify our two variables by means of a random walk model:

$$
G D P_{t}=G D P_{t-1}+\varepsilon_{1 t}=G D P_{0}+\sum_{i=1}^{t} \varepsilon_{1 i}
$$

and

$$
\operatorname{Energy}_{t}=\operatorname{Energ}_{t-1}+\varepsilon_{2 t}=\operatorname{Energ}_{0}+\sum_{i=1}^{t} \varepsilon_{2 i}
$$

where $t=1,2, \ldots T$; the constants $G D P_{0}$ and Energy $y_{0}$ are the initial constant values; and the variables $\varepsilon_{1 i}$ and $\varepsilon_{2 i}$ are white noise disturbance terms. The shocks, positive and negative, are denoted as follows: $\varepsilon_{1 i}^{+}=\max \left(\varepsilon_{1 i}, 0\right) ; \varepsilon_{2 i}^{+}=\max \left(\varepsilon_{2 i}, 0\right) ; \varepsilon_{1 i}^{-}=$ $\min \left(\varepsilon_{1 i}, 0\right) ; \varepsilon_{2 i}^{-}=\min \left(\varepsilon_{2 i}, 0\right)$, respectively. Grouping these terms as $\varepsilon_{1 i}=\varepsilon_{1 i}^{+}+\varepsilon_{1 i}^{-}$ and $\varepsilon_{2 i}=\varepsilon_{2 i}^{+}+\varepsilon_{2 i}^{-}$, we can write out the following:

$$
\begin{aligned}
& G D P_{t}=G D P_{t-1}+\varepsilon_{1 t}=G D P_{0}+\sum_{i=1}^{t} \varepsilon_{1 i}^{+}+\sum_{\square=1}^{t} \varepsilon_{1 i}^{-} \\
& G D P_{t}=G D P_{t-1}+\varepsilon_{1 t}=G D P_{0}+\sum_{i=1}^{t} \varepsilon_{1 i}^{+}+\sum_{i=1}^{t} \varepsilon_{1 i}^{-}
\end{aligned}
$$


Therefore, positive and negative shocks can be written as follows:

$$
G D P_{t}^{+}=\sum_{i=1}^{t} \varepsilon_{1 i}^{+} ; G D P_{t}^{-}=\sum_{i=1}^{t} \varepsilon_{1 i}^{-} ; \text {Energy }_{t}^{+}=\sum_{i=1}^{t} \varepsilon_{2 i}^{+} ; \text {Energy }_{t}^{-}=\sum_{i=1}^{t} \varepsilon
$$

Assuming that $y_{t}^{+}=\left(G D P_{t}^{+}\right.$, Energy $\left._{t}^{+}\right), y_{t}^{-}=\left(G D P_{t}^{-}, \operatorname{Energ}_{t}^{-}\right), y_{t}^{ \pm}=$ $\left(G D P_{t}^{+}, E n e r g y_{1 t}^{-}\right)$, and $y_{t}^{\mp}=\left(G D P_{t}^{-}, E n e r g y_{1 t}^{+}\right)$, the causal relationship between the variables can be tested using a vector autoregressive model VAR of order $p$, for lag order $r=(1, \ldots, p)$. To run a Wald test, the $\operatorname{VAR}(p)$ model can be written in a compact form (e.g., for the first combination, $y_{t}^{+}$):

$Y=D Z+\delta$, where

$Y:=\left(y_{1}^{+}, \ldots, y_{T}^{+}\right)(n \times T)$ matrix

$D:=\left(v, A_{1} \ldots, A_{p}\right)(n x(1+n p))$ matrix

$Z_{t}:=\left(\begin{array}{c}1 \\ y_{t}^{+} \\ y^{+} t-1 \\ \vdots \\ y_{t-p+1}^{+}\end{array}\right)((1+n p) x 1)$ matrix, for $t=1, \ldots, T$,

$Z:=\left(Z_{0} \ldots, Z_{T-1}\right)((1+n p) \times T)$ matrix, and

$\delta:=\left(u_{1}^{+}, \ldots, u_{T}^{+}\right)(n \times T)$ matrix

The MWald statistic is $(C \beta)^{\prime}\left[C\left(\left(Z^{\prime} Z\right)^{-1} \otimes S_{U}\right) C^{\prime}\right]^{-1}(C \beta)$, where $\beta=\operatorname{vec}(D)$, and $\operatorname{vec}(\cdot)$ is the column-stacking operator; $\otimes$ is the Kronecker product; $C$ is a $p x n(1+n p)$ indicator matrix with elements of one for restricted parameters and zeros for the rest of the parameters; and $S_{U}=\frac{\widehat{\delta}_{U}^{\prime} \widehat{\delta}_{U}}{T-q}$, where $q$ is the number of parameters in each equation of the VAR model. Under the assumption of normality, the Wald statistic follows an asymptotic $\chi^{2}$ distribution with the same degrees of freedom as the number of restrictions to be tested (in our case, equal to $p$ ). The null hypothesis of non-Granger 
causality, $H_{0}: C \beta=0$, is rejected at the $\alpha$ level of significance $(1 \%, 5 \%$ or $10 \%)$ according to the bootstrap critical values generated by the GAUSS software.

\section{Empirical Results: Granger causality findings}

According to the econometric strategy previously described, in this section, we present the empirical findings on the Granger causality relationships established between the energy consumption by source and growth, allowing non-linear behavior between the variables using the methodology suggested by Toda and Yamamoto [2] and Hatemi-J [1]. In the next subsections, the results of these approaches are reported as distinguishing according to our goals: a) Table 2 presents the total primary energy; b) Table 3 includes the supply-side viewpoint for each energy source; c) Table 4 reports the demand-side viewpoint for each economic sector. It would make the reading more interesting and smooth because the causality results vary for different tests. In addition, to explore the issue in depth, we estimated asymmetric Granger-causality test statistics and tested their significance with 5.000 bootstrapped critical values. The estimation results are presented in Tables 2-4, while Table 5 summarizes the main results.

By looking at Table 2, we can see that linear and asymmetric non Grangercausality only from GDP is rejected at the $1 \%$ level of significance for total primary consumption. For all cases of the opposite causality, i.e., from energy consumption to GDP, we find that the null hypothesis that energy does not Granger-cause GDP is nonrejected.

Attending on the supply side, results are provided in table 3. These results also confirm the causality from GDP to energy except in the case of renewables energies. On the opposite, only in the case of petroleum and nuclear consumption we reject the null hypothesis that energy does not Granger caused GDP. In consequence, our findings also show evidence of the bidirectional Granger-causal relationship between energy consumption and economic growth in the petroleum and nuclear energy sources. Conversely, the results from asymmetric Granger-causality analysis reveal the importance to distinguish the direction of the causality. In the positive approach, it is important to distinguish the direction of the causality. Although the results are similar to the previous findings, in the case of a positive relationship from energy to GDP, we only reject the null hypothesis clearly in the petroleum case. Regarding the GDP to energy relationship, our results reveal that petroleum consumption is not Granger 
caused by GDP. When the Wald test statistic is used for negative shocks, the null hypothesis for non-Granger-causality from GDP to energy consumption is rejected only in three cases: total primary energy consumption, total fossil and coal. In the reverse case, from energy to GDP, petroleum and nuclear are the cases where we can reject the null hypothesis of causality.

Table 4, regarding the economic sectors, we find bidirectional causality in the commercial and industrial sector, whereas the transportation sector shows causality from GDP to energy consumption, and, finally, the reverse causality is achieved in the residential sector. For its par, the positive shocks in GDP cause positive shocks in energy consumption in the commercial and transport sector. Furthermore, focusing in the negative approach, the causality in the opposite direction appears only in the industrial sector. Finally, our results also confirm the causality from GDP to energy consumption in the industrial sector, whereas the transport sector shows the opposite behavior.

Table 2. Total energy consumption

\begin{tabular}{|c|c|c|c|c|c|c|c|c|}
\hline & \multirow{2}{*}{$\begin{array}{l}\text { Test } \\
\text { statistic }\end{array}$} & \multicolumn{3}{|c|}{ Bootstrap critical values } & \multirow{2}{*}{$\begin{array}{l}\text { Test } \\
\text { statistic }\end{array}$} & \multicolumn{3}{|c|}{ Bootstrap critical values } \\
\hline & & $1 \%$ & $5 \%$ & $10 \%$ & & $1 \%$ & $5 \%$ & $10 \%$ \\
\hline & \multicolumn{4}{|c|}{ Energy $\nRightarrow G D P$} & \multicolumn{4}{|c|}{$G D P \nRightarrow$ Energy } \\
\hline \multirow[t]{2}{*}{ Total } & 4.013 & 11.472 & 7.498 & 6.160 & $29,980 * * *$ & 11.847 & 8.058 & 6.558 \\
\hline & \multicolumn{4}{|c|}{ Energy $^{+} \nRightarrow$ GDP $^{+}$} & \multicolumn{4}{|c|}{$\mathrm{GDP}^{+} \nRightarrow$ Energy $^{+}$} \\
\hline \multirow[t]{2}{*}{ Total } & 2.010 & 9.977 & 6.036 & 4.707 & $11.218^{* * *}$ & 9.927 & 6.444 & 4.521 \\
\hline & \multicolumn{4}{|c|}{ Energy $^{-} \nRightarrow$ GDP $^{-}$} & \multicolumn{4}{|c|}{$G D P^{-} \nRightarrow$ Energy $^{-}$} \\
\hline Total & 1.717 & 10.075 & 6.196 & 4.480 & $11.528^{* *}$ & 12.232 & 6.299 & 4.799 \\
\hline
\end{tabular}

Table 3. Energy sources, or supply side

\begin{tabular}{|c|c|c|c|c|c|c|c|c|}
\hline & \multirow{2}{*}{$\begin{array}{l}\text { Test } \\
\text { statistic }\end{array}$} & \multicolumn{3}{|c|}{ Bootstrap critical values } & \multirow{2}{*}{$\begin{array}{l}\text { Test } \\
\text { statistic }\end{array}$} & \multicolumn{3}{|c|}{ Bootstrap critical values } \\
\hline & & $1 \%$ & $5 \%$ & $10 \%$ & & $1 \%$ & $5 \%$ & $10 \%$ \\
\hline & \multicolumn{4}{|c|}{ Energy $\nRightarrow G D P$} & \multicolumn{4}{|c|}{$G D P \nRightarrow$ Energy } \\
\hline Total fossil & 3.156 & 12.378 & 7.559 & 6.215 & $30.666^{* * *}$ & 11.847 & 8.203 & 6.364 \\
\hline Coal & 0.619 & 10.152 & 6.111 & 4.512 & $17.269^{* * *}$ & 9.929 & 6.694 & 5.226 \\
\hline Natural Gas & 1.796 & 11.553 & 7.826 & 6.400 & $10.660 * *$ & 11.291 & 7.928 & 5.990 \\
\hline Petroleum & $9.424 * * *$ & 9.240 & 6.079 & 4.749 & $10.220 * * *$ & 9.650 & 6.197 & 4.475 \\
\hline Nuclear & $11.042 * *$ & 16.639 & 10.964 & 9.029 & $16.304^{* * *}$ & 15.024 & 11.025 & 9.466 \\
\hline Renewable & 0.788 & 8.503 & 5.912 & 4.554 & 0.071 & 9.491 & 5.708 & 4.272 \\
\hline
\end{tabular}




\begin{tabular}{|c|c|c|c|c|c|c|c|c|}
\hline Hydroelectric & 0.857 & 8.181 & 5.623 & 4.398 & 0.188 & 9.219 & 6.113 & 4.567 \\
\hline Geothermal & 0.739 & 10.290 & 6.483 & 4.882 & 3.447 & 9.206 & 6.157 & 4.138 \\
\hline Biomass & 3.110 & 19.137 & 14.061 & 11.276 & 8.459 & 19.329 & 13.475 & 11.431 \\
\hline & \multicolumn{4}{|c|}{ Energy $^{+} \nRightarrow G P^{+}$} & \multicolumn{4}{|c|}{ GDP $^{+} \nRightarrow$ Energy $^{+}$} \\
\hline Total fossil & 1.391 & 9.382 & 6.197 & 4.621 & $9.055^{*}$ & 9.648 & 6.530 & 4.612 \\
\hline Coal & 1.758 & 9.305 & 5.895 & 4.709 & $12.335^{* * *}$ & 9.391 & 6.102 & 4.631 \\
\hline Natural Gas & 1.290 & 10.206 & 6.309 & 4.734 & $7.501 * *$ & 9.835 & 6.167 & 4.717 \\
\hline Petroleum & $29.552 * * *$ & 23.172 & 17.258 & 13.826 & 13.010 & 21.262 & 16.171 & 13.416 \\
\hline Nuclear & 10.864 & 18.513 & 13.337 & 10.975 & $22.789 * * *$ & 18.284 & 13.515 & 11.473 \\
\hline Renewable & 0.268 & 8.928 & 6.231 & 4.687 & 0.000 & 9.787 & 5.931 & 4.853 \\
\hline Hydroelectric & 2.307 & 8.887 & 6.065 & 4.604 & 0.198 & 9.681 & 6.179 & 4.873 \\
\hline Geothermal & 2.473 & 10.781 & 6.487 & 4.488 & $14.724 * * *$ & 10.383 & 6.544 & 4.975 \\
\hline \multirow[t]{2}{*}{ Biomass } & 4.438 & 11.581 & 6.132 & 4.824 & 1.270 & 11.065 & 6.275 & 4.821 \\
\hline & \multicolumn{4}{|c|}{ Energy $^{-} \nRightarrow G D P^{-}$} & \multicolumn{4}{|c|}{$G P^{-} \nRightarrow$ Energy $^{-}$} \\
\hline Total fossil & 1.523 & 9.653 & 6.308 & 4.799 & $15.806^{* * *}$ & 11.434 & 6.263 & 4.760 \\
\hline Coal & 0.325 & 12.451 & 7.013 & 4.981 & $8.173^{* *}$ & 11.759 & 6.351 & 4.759 \\
\hline Natural Gas & 4.645 & 12.189 & 8.217 & 6.397 & 5.686 & 12.897 & 7.913 & 6.008 \\
\hline Petroleum & $41.086^{* * *}$ & 16.614 & 10.190 & 8.060 & 1.227 & 14.414 & 10.289 & 8.389 \\
\hline Nuclear & $27.243^{* *}$ & 34.072 & 18.488 & 12.049 & 2.753 & 23.209 & 13.992 & 10.222 \\
\hline Renewable & 1.576 & 13.077 & 6.514 & 4.599 & 2.130 & 11.992 & 6.771 & 4.777 \\
\hline Hydroelectric & 3.882 & 13.356 & 6.643 & 4.787 & 0.007 & 10.862 & 6.220 & 4.786 \\
\hline Geothermal & 1.585 & 14.033 & 6.999 & 4.805 & 1.901 & 14.263 & 7.814 & 4.681 \\
\hline
\end{tabular}

Notes: ${ }^{*} * *$ and $* * *$ indicate statistical significance at 10,5 and $1 \%$ level respectively. Critical values are obtained from 5000 bootstrap replications.

Table 4. Economic sectors, or Demand side

\begin{tabular}{|c|c|c|c|c|c|c|c|c|}
\hline \multirow[b]{2}{*}{ Global } & \multirow{2}{*}{$\begin{array}{l}\text { Test } \\
\text { statistic }\end{array}$} & \multicolumn{3}{|c|}{ Bootstrap critical values } & \multirow{2}{*}{$\begin{array}{l}\text { Test } \\
\text { statistic }\end{array}$} & \multicolumn{3}{|c|}{ Bootstrap critical values } \\
\hline & & $1 \%$ & $5 \%$ & $10 \%$ & & $1 \%$ & $5 \%$ & $10 \%$ \\
\hline & \multicolumn{4}{|c|}{ Energy $\nRightarrow G D P$} & \multicolumn{4}{|c|}{$G D P \nRightarrow$ Energy } \\
\hline Residential & $7.384 *$ & 13.369 & 8.613 & 6.885 & 4.522 & 11.333 & 8.012 & 6.273 \\
\hline Commercial & $10.535^{* *}$ & 12.384 & 9.413 & 7.848 & $18.170^{* * *}$ & 14.328 & 10.252 & 8.214 \\
\hline Industrial & $9.704 * *$ & 10.657 & 6.454 & 5.030 & $33.535^{* * *}$ & 10.176 & 6.620 & 4.736 \\
\hline \multirow[t]{2}{*}{ Transportation } & 0.347 & 9.424 & 6.074 & 4.820 & $18.818^{* * *}$ & 10.504 & 6.106 & 4.657 \\
\hline & \multicolumn{4}{|c|}{ Energy $^{+} \nRightarrow{G D P P^{+}}^{+}$} & \multicolumn{4}{|c|}{ GDP $^{+} \nRightarrow$ Energy $^{+}$} \\
\hline Residential & 4.546 & 12.216 & 8.369 & 6.274 & 3.229 & 12.531 & 8.468 & 6.538 \\
\hline Commercial & 2.300 & 9.011 & 5.950 & 4.723 & $8.635^{* *}$ & 9.894 & 6.422 & 4.772 \\
\hline Industrial & $11.386^{* * *}$ & 10.631 & 6.095 & 4.463 & 3.978 & 9.849 & 5.822 & 4.555 \\
\hline \multirow[t]{2}{*}{ Transportation } & 0.384 & 9.861 & 6.513 & 5.053 & $7.917^{* *}$ & 9.698 & 6.023 & 4.529 \\
\hline & \multicolumn{4}{|c|}{ Energy $^{-} \nRightarrow G^{-} P^{-}$} & \multicolumn{4}{|c|}{ GDP $^{-} \nRightarrow$ Energy $^{-}$} \\
\hline Residential & 1.710 & 14.494 & 7.829 & 6.330 & 2.512 & 12.995 & 8.508 & 6.586 \\
\hline Commercial & 6.332 & 18.049 & 11.418 & 9.113 & 1.982 & 16.161 & 10.553 & 7.901 \\
\hline Industrial & 7.583 & 24.005 & 16.078 & 12.988 & $84.300^{* * *}$ & 22.803 & 16.859 & 13.762 \\
\hline Transportation & $46.154^{* * *}$ & 28.162 & 14.596 & 11.107 & 5.878 & 15.853 & 11.630 & 9.859 \\
\hline
\end{tabular}

Notes: ${ }^{*}{ }^{* *}$ and ${ }^{* * *}$ indicate statistical significance at 10,5 and $1 \%$ level respectively. Critical values are obtained from 5000 bootstrap replications. 
Finally, to better meet the set of found results, the results are synthesized in Table 5. Among the most relevant findings, according to the energy sources or supply side, we note that the conservation hypothesis is supported in the case of total fossils (including natural gas and coal), nuclear and total primary energy sources. Additionally, the relationship established by the feedback hypothesis is supported in the case of petroleum and nuclear energies, whereas the neutrality hypothesis is confirmed only for renewables. When the asymmetries are observed, we confirmed that the growth hypothesis is an interesting result because only the petroleum energy source has an important role in the positive shocks of GDP. Thus, we can see that negative shocks in the GDP occur when there are falls in the consumption of oil and nuclear energy. Moreover, it seems clear that the conservation hypothesis is very clear with respect to primary energy consumption, total fossil and coal, independent of the direction of the shocks in the economy. In this sense, the conservation hypothesis is supported for positive shocks in natural gas and nuclear energy; however, we do not find evidence for negative shocks. For renewable energies, the results reveal again the neutrality hypothesis.

The approximation made for the economic sectors, i.e. from demand side, provide different results. The industrial sector seems to be the determinant of economic growth. In this sense, the growth hypothesis is confirmed in the linear approximation and the positive effects. By contrast, in response to the negative effects, the conservation hypothesis is shown in the industrial sector. The commercial and transportation sectors also confirm the hypothesis of conservation in positive effects.

Table 5. Summary of Results

\begin{tabular}{|c|c|c|c|c|}
\hline \multirow{2}{*}{ Objective } & \multirow{2}{*}{$\begin{array}{c}H_{0}: \text { Energy } \nRightarrow \text { GDP } \\
\text { Growth }\end{array}$} & $H_{0}:$ GDP $\nRightarrow$ Energy & Bidirectionality & No causality \\
\hline & & Conservation & Feedback & Neutrality \\
\hline \multirow[t]{3}{*}{ Total } & & $\checkmark \quad$ Linear & & \\
\hline & & $\checkmark \quad$ Positive & & \\
\hline & & $\checkmark \quad$ Negative & & \\
\hline \multicolumn{5}{|l|}{ Supply side } \\
\hline & $\checkmark \quad$ Positive: & Linear: Total & $\checkmark \quad$ Linear: & \\
\hline & Petroleum & fossil, coal, & Petroleum & \\
\hline & $\checkmark \quad$ Negative: & natural gas & and nuclear & \\
\hline & Petroleum and & $\checkmark \quad$ Positive: Total & & \\
\hline & Nuclear & fossil, coal, & & \\
\hline & & natural gas, & & \\
\hline & & nuclear and & & \\
\hline
\end{tabular}




\begin{tabular}{|c|c|c|c|c|c|c|}
\hline & & & $\checkmark$ & $\begin{array}{l}\text { geothermal. } \\
\text { Negative: Total } \\
\text { fossil and coal }\end{array}$ & & \\
\hline \multirow{6}{*}{ Demand side } & \multirow[t]{2}{*}{$\checkmark$} & Linear: & $\checkmark$ & Linear: & \multirow[t]{6}{*}{$\checkmark$} & \multirow{6}{*}{$\begin{array}{l}\text { Linear: } \\
\text { Comercial } \\
\text { and industrial }\end{array}$} \\
\hline & & Residential & & Transportation & & \\
\hline & \multirow[t]{2}{*}{$\checkmark$} & Positive: & $\checkmark$ & Positive: & & \\
\hline & & Industrial. & & Comercial and & & \\
\hline & \multirow[t]{2}{*}{$\checkmark$} & Negative: & & transportation. & & \\
\hline & & Transportation & Nega & ve: Industrial & & \\
\hline
\end{tabular}

\section{Conclusions}

Determination of the causal link between growth and energy consumption has captured the interest of researchers, academics and politicians because of its implications for economic development, the environment, and the appropriate use of energy resources. Unfortunately, although a large number of articles have been devoted to trying to explain this relationship, there is a surprising lack of consensus in the literature on the directions of causality. This study has analyzed the impact of GDP shocks in the USA on primary energy consumption and the reverse impact, distinguishing by total fossil (coal, natural gas and petroleum), nuclear, and renewable (hydroelectric, geothermal and biomass) and distinguishing by economic sectors for the period 1973:1 to 2015:2. To this end, we applied the Toda and Yamamoto [2] and Hatemi-J. [1] approaches for a Granger causality analysis from a time series perspective to evaluate the existence of asymmetries in this bidirectional relationship.

Our empirical results suggest that GDP causes energy consumption, i.e., the conservation hypothesis is confirmed independently of the linear or asymmetric perspective. When causality is observed on the side of supply, energy sources confirm different assumptions and fundamentally distinguish between renewable and nonrenewable energy. On the one hand, we have nonrenewable energy in a causal relationship with GDP, confirming the neutral hypothesis. However, the behaviour within the non-renewable energy is mixed. Although the conservation hypothesis is confirmed for most sources, nuclear energy and oil either have different patterns or asymmetrical linear function analyses. Consequently, our work guarantees that oil appears as the source that is most determinant for growth energy; it is the only energy source that confirms the hypothesis of growth. On the demand side, there is a 
bidirectional causality between sectors and energy consumption. In addition, positive shocks in the industrial sector would generate positive shocks in GDP.

In summary, due to the observation of different patterns by energy sources and sectors, and most importantly, the effect of economic shocks, it would be advisable for policy makers to consider the time when policy measures are taken and to establish a suitable framework for a balance between renewable and nonrenewable energy sources."

\section{References}

[1] Hatemi-JA. Asymmetric causality tests with an application, Empir Econ, 2012; 43(1), pages 447-456, August.

[2] Toda HI, Yamamoto T. Statistical inference in vector autoregressions with possibly integrated processes. J Econometrics 1995;(66): 225-50.

[3] Flavin C, Aeck MH. The Potential Role of Renewable Energy in Meeting the Millennium Development Goals. Worldwatch Institute, 2005. Washington, DC.

[4] IEA. World Energy Outlook 2009 Edition. International Energy Agency. ISBN: 978-92-64-06130-9.

[5] REN21: Renewables 2011: Global status report. www.ren21.net.

[6] Aslan AN, Apergis, N, Yildirim S. Causality between energy consumption and GDP in the U.S.: evidence from wavelet analysis. Front. Energy 2014; 8(1): 1-8. DOI 10.1007/s11708-013-0290-6.

[7] Menegaki AN. On energy consumption and GDP studies; A meta-analysis of the last two decades. Renew. Sustain. Energy Rev. 2014; (29): 31-36.

[8] Solow RM. Technical change and the aggregate production function. Rev. Econ. Stat. 1957;(39): 312320.

[9] Baumol WJ. On the possibility of continuing expansion of finite resources. Kyklos 1986, 39; 167179.

[10] Kraft J, Kraft A. On the relationship between energy and GNP. J Energy Dev. 1978; 3:401-3.

[11] Stern, D. I. A multivariate cointegration analysis of the role of energy in the US macroeconomy. Energy Economics, 2000; 22 (2):267-283.

[12] Sari, R. and Soytas, U. The Growth of Income and Energy Consumption in Six Developing Countries Energy Policy, 2007; 35 (2):889-98. 
[13] Narayan, Paresh Kumar, and Baljeet Singh. The electricity consumption and GDP nexus for the Fiji Island. Energy Economics, 2007; 29 (6):1141-1150.

[14] Rafiq, S. and Salim, R. A. Temporal causality between energy consumption and income in six Asian emerging countries. Applied Economics Quarterly, 2010; 55(4), 2010.

[15] Camarero M. et al. (2015) Variable selection in the analysis of energy consumption-growth nexus. Energy Economics, 52, 2017-215.

[16] Article provided by Elsevier in its journal Journal of Econometrics. Volume (Year): 19 (1982), 2-3 (August): 367-378.

[17] Payne JE. Survey of the international evidence on the casual relationship between energy consumption and growth. J. Econ. Stud. 2010;37(1): 53-95.

[18] Smyth R, Narayan PK. Applied econometrics and implications for energy economics research. Energy Econ 2015; 50:351-8.

[19] Özturk I. A literature survey on energy-growth nexus. Energy Policy 2010;38 (1):340-9.

[20] Omri A. An international literature survey on energy-economic growth nexus: Evidence from country-specific studies. Renew. Sustain. Energy Rev. 2014; (38): 951-959

[21] Kalimeris P, Richardson C, Bithas K. A meta-analysis investigation of the direction of the energyGDP causal relationship: implications for the growth-degrowth dialogue. J Clean Prod. 2014; (67): 1-13.

[22] Ohler A, Fetters I. The causal relationship between renewable electricity generation and GDP growth: A study of energy sources. Energy Econ. 2014; (43): 125-139.

[23] Belke A, Dobnik F, Dreger C. Energy consumption and economic growth: new insights into the cointegration relationship. Energy Econ. 2011; 33 (5): 782-789.

[24] Gross C. Explaining the (non-) causality between energy and economic growth in the U.S.-A multivariate sectoral analysis. Energy Econ. 2012;(34): 489-499.

[25] Bowden N, Payne, JE. The causal relationship between U.S. Energy consumption and real output: a disaggregated analysis. J. Policy Model. 2009; 31(2): 180-188.

[26] Zachariadis T. Exploring the relationship between energy use and economic growth with bivariate models: new evidence from G-7 countries. Energy Econ. 2007;29(6): 1233-1253.

[27] Simpson E. The interpretation of interaction in contingency tables. J. R. Stat. Soc.Ser. B Methodol. 1951; 13 (2): 238-241.

[28] Bowden N, Payne JE. Sectoral analysis of the causal relationship between renewable and non- 
renewable energy consumption and real output in the US. Energy Sources, Part B: Econ Plan Policy. 2010; 5: 400-8.

[29] Omri A, Mabrouk NB, Sassi-Tmar A. Modeling the causal linkages between nuclear energy, renewable energy and economic growth in developed and developing countries. Renew. Sustain. Energy Rev. 2015; 42: 1012-1022.

[30] Stern DI. Energy and economic growth in the USA. A multivariate approach. Energ. Econ. 1993; 15 (2): $137-150$.

[31] Sari R, Ewing BT, Soytas U. The relationship between disaggregate energy consumption and industrial production in the United States: An ARDL approach. Energ. Econ. 2008; 30 (5): 2302-2313.

[32] Kum H. Ocal O. Aslan A. The relationship between among natural gas energy consumption, capital and economic growth: Bootstrap-corrected Causality tests from G-7 countries. Renew. Sustain. Energy Rev. 2012; 12: 2361-2365.

[33] Payne JE. On biomass energy consumption and real output in the US. Energy istepisources Part B: Econ Plan Policy 2011a;6: 47-52.

[34] Payne JE. US disaggregate fossil fuel consumption and real gdp: an empirical isẸp: Sources Part B: Econ Plan Policy. 2011b;6: 63-8.

[35] Menyah K, Wolde-Rufael Y. Electricity consumption and economic growth in transition countries: A revisit using bootstrap panel Granger causality analysis. Energy Econ. 2015;44: 325-330.

[36] Payne JE. On the dynamics of energy consumption and output in the US. Appl Energy 2009; 86(4): $575-7$.

[37] Apergis N, Danuletiu DC. Renewable Energy and Economic Growth: Evidence from the Sign of Panel Long-Run Causality. IJEEP. 2014;(4),4: 578-587.

[38] Yildirım ED. Sukruoglu D, Aslan A. Energy consumption and economic growth in the next 11 countries: The bootstrapped autoregressive metric causality approach. Energy Econ. 2014;(44): 14-21.

[39] Bildirici ME, Bakirtas T. The relationship among oil, natural gas and coal consumption and economic growth in BRICTS (Brazil, Russian, India, China, Turkey and South Africa) countries. Energy 2014;(65): 134-144.

[40] Tiwari AK. The asymmetric Granger-causality analysis between energy consumption and income in the United States. Renew. Sustain. Energy Rev. 2014;(36): 362-369.

[41] Sebri M, Ben-Salha O. On the causal dynamics between economic growth, renewable energy consumption, $\mathrm{CO} 2$ emissions and trade openness: Fresh evidence from BRICS countries. Renew. Sustain. 
Energy Rev. 2014;(39): 14-23.

[42] Śmiech S, Papież M. Energy consumption and economic growth in the light of meeting the targets of energy policy in the EU: The bootstrap panel Granger causality approach. Energy Policy. 2014;(71): 118129.

[43] Ucan O, Aricioglu E, Yucel F. Energy Consumption and Economic Growth Nexus: Evidence from

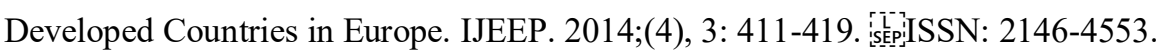

[44] Ozturk I, Bilgili F. Economic growth and biomass consumption nexus: Dynamic panel analysis for Sub-Sahara African countries. Appl Energy. 2015;(137): 110-116.

[45] Bilgili, F. And I. Ozturk. Biomass energy and economic growth nexus in G7 countries: Evidence from dynamic panel data. Renew. Sustain. Energy Rev. 2015;(49): 132-138

[46] Bloch H, Rafiq S, Salim R.. Economic growth with coal, oil and renewable energy consumption in China: Prospects for fuel substitution. Econ Model. 2015;(44): 104-115.

[47] Iyke BN. Electricity consumption and economic growth in Nigeria: A revisit of the energy-growth debate. Energy Econ. 2015;(51): 166-176.

[48] Granger CWJ, Yoon G. Hidden Cointegration (January 2002). U. of California, Economics Working Paper No. 2002-02. http://dx.doi.org/10.2139/ssrn.313831.

[49] Johansen S, Juselius K. Maximum Likelihood Estimation and Inference on Cointegration with Applications to the Demand for Money. Oxford Bull. Econ. Statist, 1990; (52), 2: 169-210.

[50] Zapata HO, Rambaldi AN. Monte Cario evidence on cointegration and causation. Oxford Bull. Econ. Statist. 1997;(59): 285-298.

[51] Maddala GS, Kim I-M. Unit Roots, Cointegration and Structural Change. Oxford University Press, Oxford. 1998.

[52] Pesaran MH, Shin Y, Smith R. Bond testing approaches to the analysis of long-run relationships. J Appl Econometrics 2001;16:289-26.

[53] Clarke JA, Mirza S. A Comparison of some common methods for detecting Granger noncausality Journal of Statistical Computation and Simulation 2006;(76), 3: 207-231.

[54] Booth GG, Ciner C. German dominance in the European Monetary System: a reprise using robust Wald tests. App Econ Lett, 2005;(12), 8: 463-466. 


\section{APPENDIX}

A1. Time plots of the variables (All the variables included in this append are expressed in logs).

A.1.1 Energy consumption by source and sectors (measured in quadrillion British Thermal Units (BTu)).
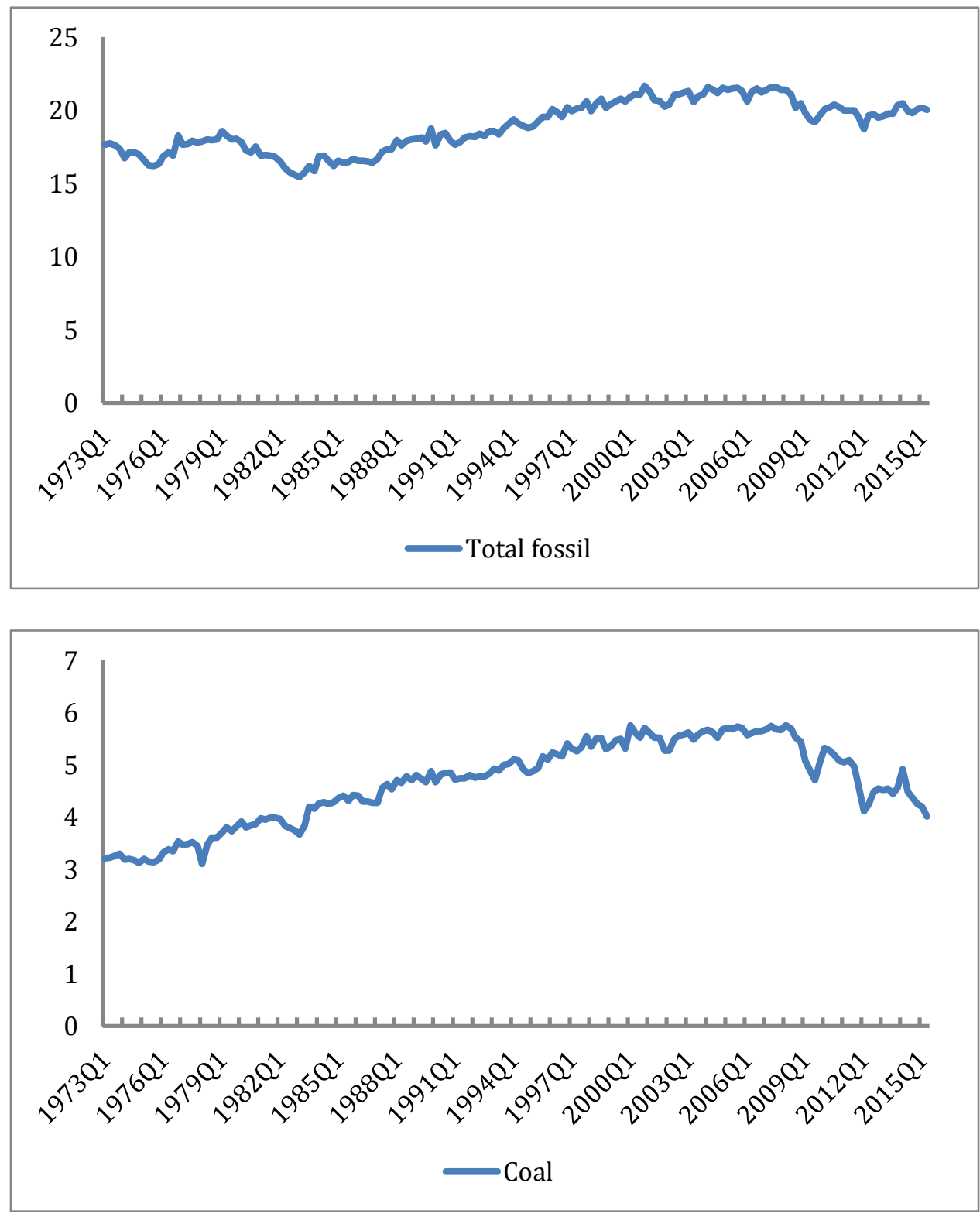

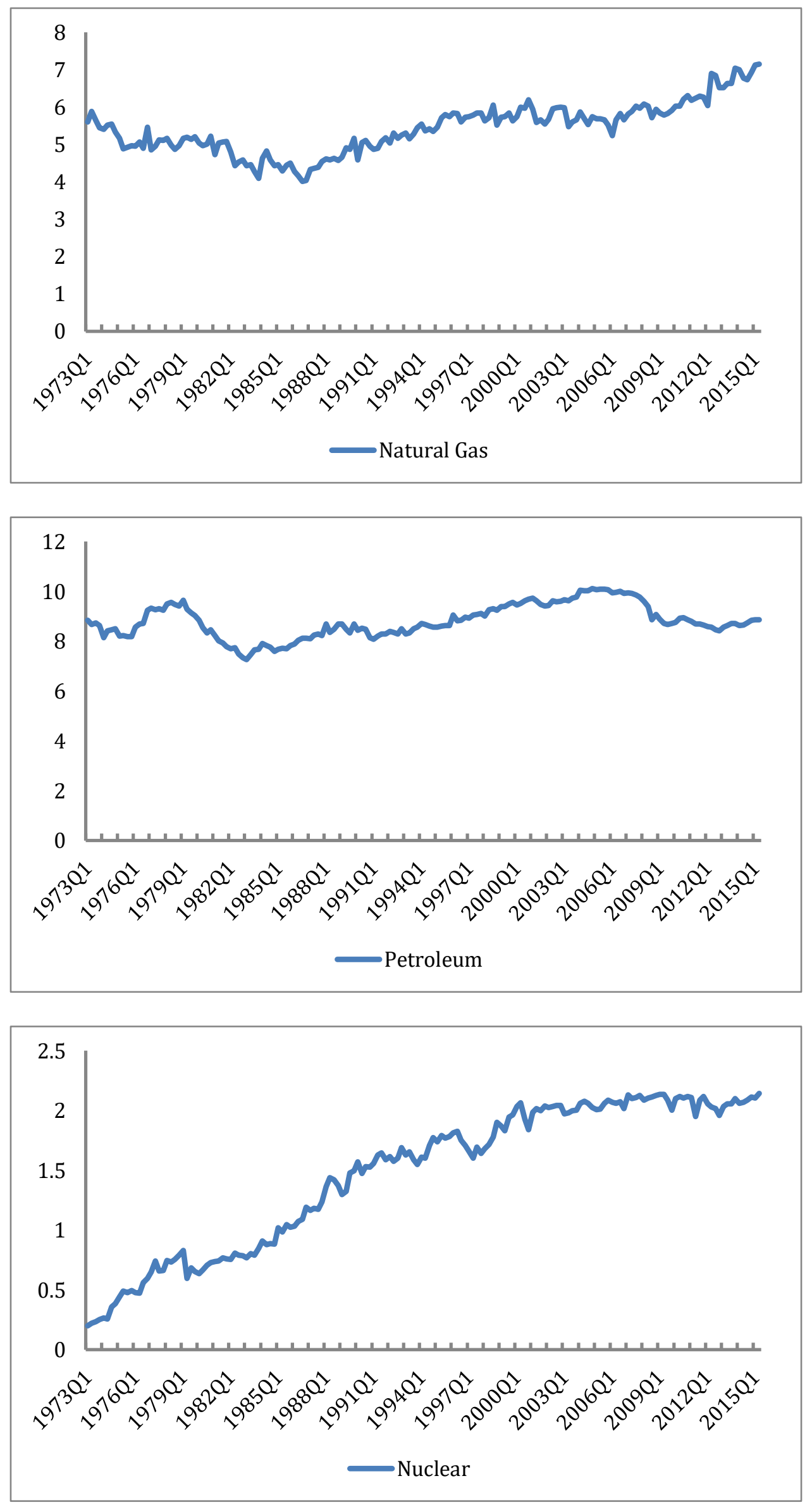

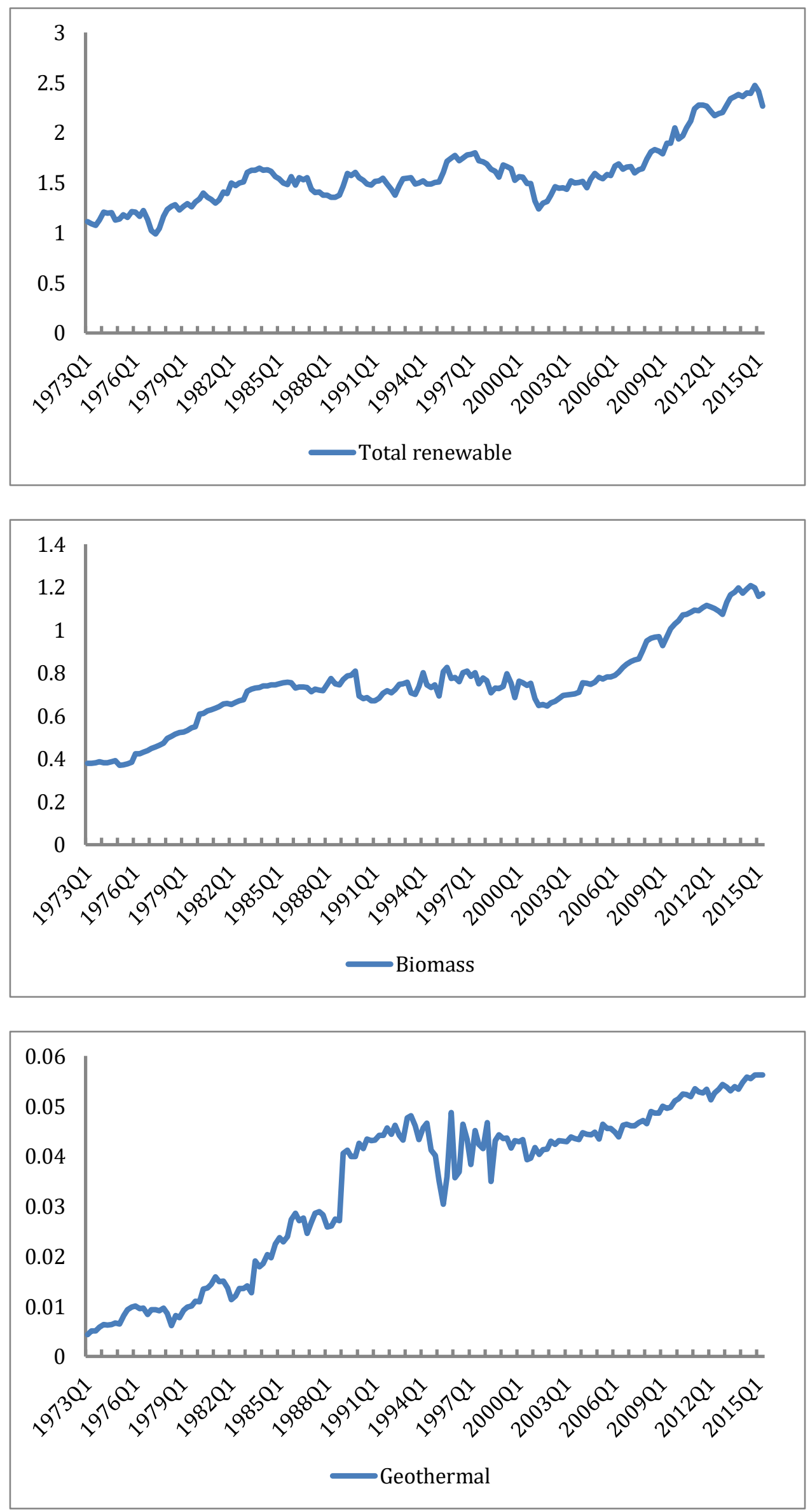

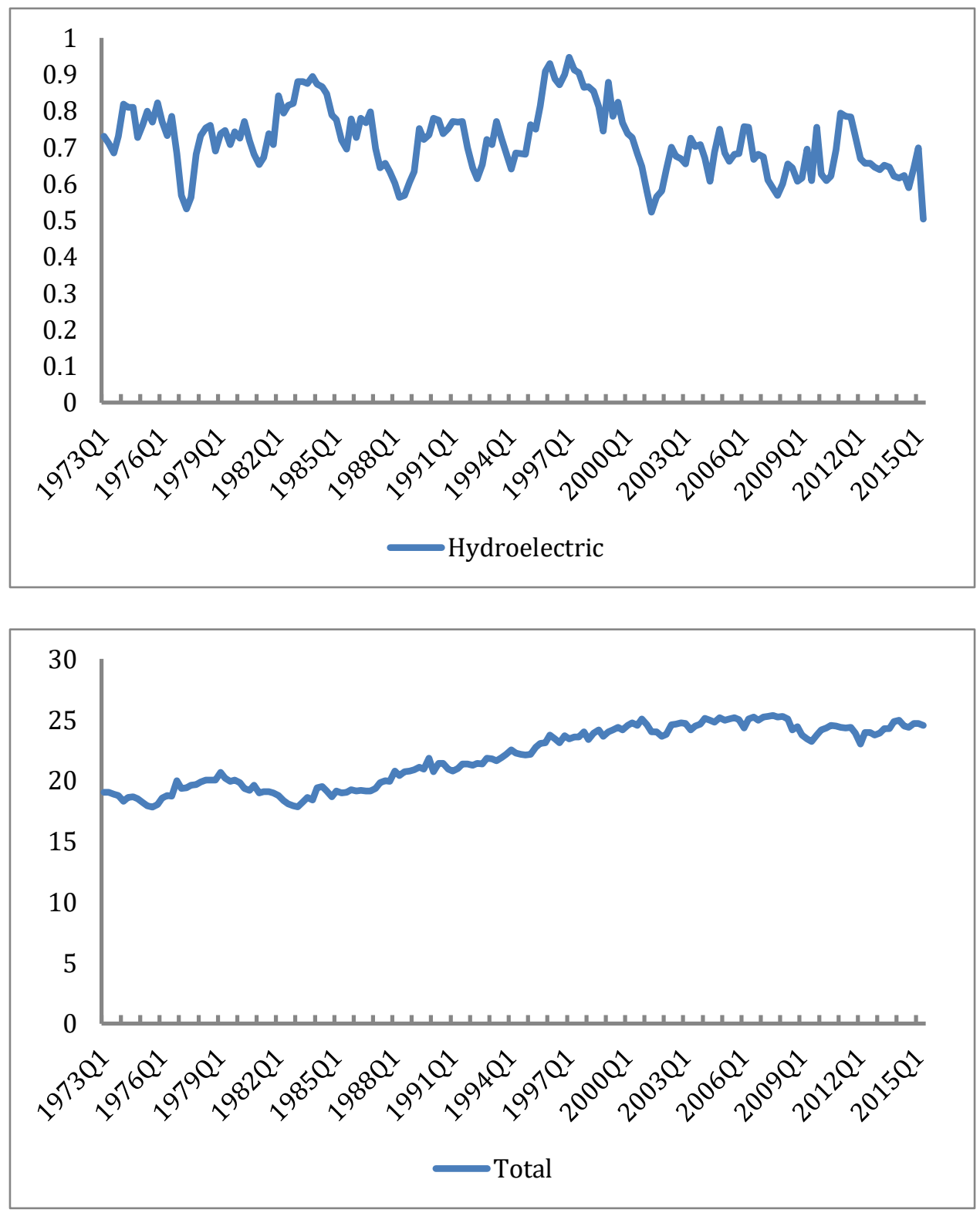
A.1.2 Gross domestic product is expressed in billions of chained 2009 dollars (Quarterly data, seasonally adjusted annual rates)

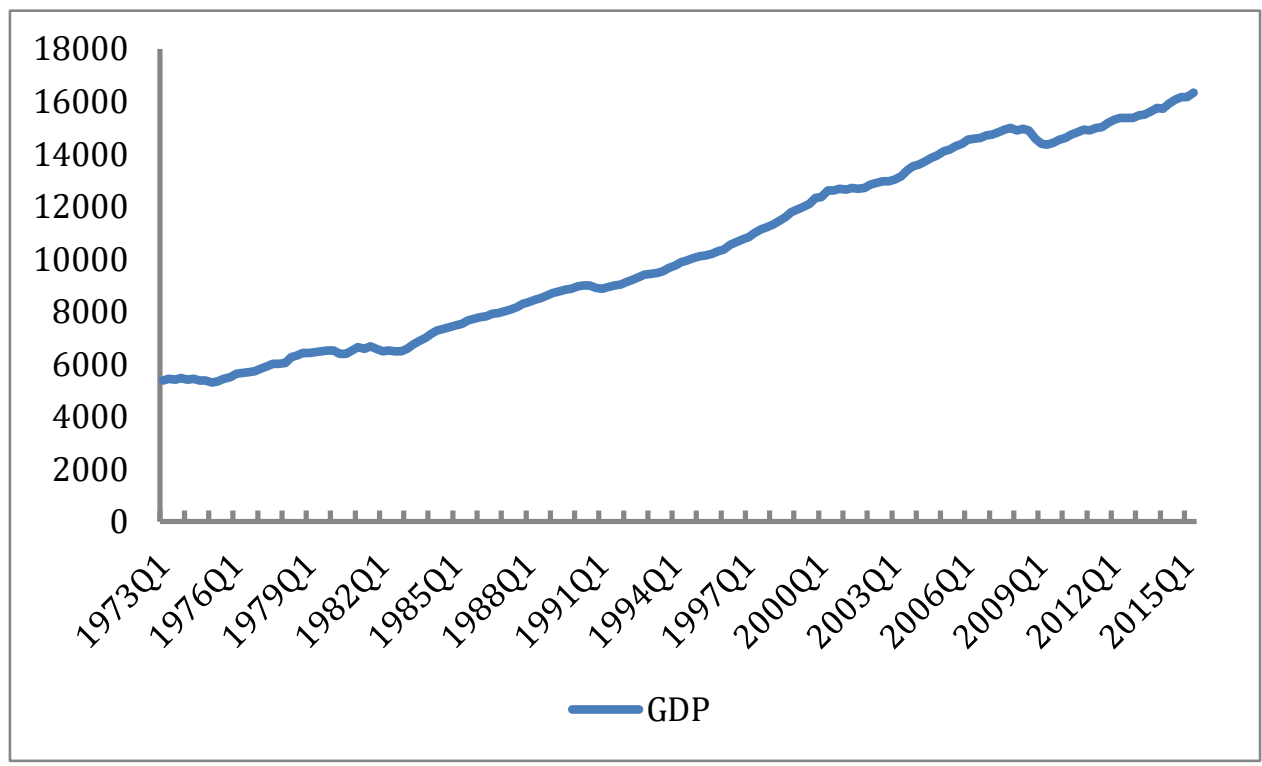

